\title{
The Thrown Leader
}

\author{
Wiley Souba ${ }^{1}$, Matthew Souba ${ }^{2}$ \\ ${ }^{1}$ Department of Surgery, Geisel School of Medicine, Dartmouth, UK \\ ${ }^{2}$ Department of Philosophy, Ohio State University, Columbus, Ohio, USA \\ Email:chip.souba@dartmouth.edu,souba.2@osu.edu
}

How to cite this paper: Souba, W., \& Souba, M. (2017). The Thrown Leader. Open Journal of Leadership, 6, 135-141. https://doi.org/10.4236/oj1.2017.64010

Received: October 22, 2017

Accepted: November 28, 2017

Published: December 1, 2017

Copyright $(92017$ by authors and Scientific Research Publishing Inc. This work is licensed under the Creative Commons Attribution International License (CC BY 4.0).

http://creativecommons.org/licenses/by/4.0/

\begin{abstract}
The term "thrownness" designates our inevitable submission to life's challenges and predicaments, often determined arbitrarily by chance or by destiny. We inescapably find ourselves thrown because the world matters to us in some way or another. The term has major implications for effective leadership since leaders are invariably thrown into vexing circumstances or inherit problems that they had nothing to do with creating in the first place. Effective leaders attend to and "throw off" their thrownness by choosing judiciously from those possibilities (actions) that are available to them in a particular situation. Our "being" as leaders is always a struggle between thrownness and possibility because the undertakings we engage in and the people we interact with-our students, our colleagues, and our families-matter to us in some way or another. We care about our future and the future of our work; that's what makes the sting of being thrown so raw. But rather than avoiding or disengaging from their challenges, authentic leaders take responsibility for what was, what is, and what will be, regardless of the circumstances they are thrown into. Acceptance of the randomness and inevitability of being thrown, with its associated aggravations and annoyances, is a hallmark of effective leaders. This grants leaders a somewhat paradoxical gateway to freedom, a journey on which they can discover purpose in their thrown humanity.
\end{abstract}

\section{Keywords}

Thrownness, Resilience, Human "Being”, Responsibility, Being a Leader, Inward Journey

\section{Introduction}

Consider this: You have just assumed a new leadership position. You're excited and committed. But, in a few short weeks, you discover that the financial mess you inherited is much bigger than you were led to believe. To galvanize the faculty, you launch a successful leadership program but a group of professors from 
another school complain that you're encroaching on their turf. When you confront a rock star researcher who refuses to play by the rules, the higher-ups in the university tell you to back-off, saying: "We can't afford to lose him. He has a ton of grants." A few years later, new leadership arrives and you are told that your contract will not be renewed.

Sound familiar? Leaders are invariably thrown into circumstances or inherit problems that they had nothing to do with creating in the first place. And, in spite of their good intentions, no good deed goes unpunished.

\section{The Thrown Nature of Leadership}

A century ago, the German philosopher Martin Heidegger coined the term "thrownness" to designate our inevitable submission to life and its challenges and tribulations. A human being, writes Heidegger, "is not a free-floating self-projection; its character is determined by thrownness as a Fact of the entity which it is" (Heidegger, 1962 [1927]). Thus, "being-in-the-world-thrown" is the kind of being (existence) we humans have.

"Into this world we're thrown, like a dog without a bone" crooned the Doors front man, Jim Morrison, 50 years ago (The Doors, 1971). Each of us is continuously plunged or "thrown" into circumstances that often seem to have been shaped arbitrarily by chance or by destiny. We are born into conditions beyond our control. We may be born in Venezuela or Canada or Kenya; we may be born to wealthy parents or poor parents; we may grow up in an abusive family or a loving one. This matrix shapes and constrains our ways of being and acting for our entire lives. Moreover, we are often thrown, seemingly randomly, into circumstances that we had no role whatsoever in creating. We're like the junior faculty member who's told "The chair is ill, the vice-chair has taken another job, and the other faculty are too busy. As of now, you are the chair." Almost instantaneously, you have assumed the role of department chair even though you have no experience, don't know the issues, have no interest in the position, but have no choice.

Our thrown circumstances include our culture, our social status, our personality, and our innate intelligence, all of which shape the specific circumstances we are dealing with moment to moment, with all of their associated frustrations and stresses that we do not choose. The world we are thrown into often seems indifferent to our concerns but we must still find something to live for that gives our lives purpose. In the words of the Spanish philosopher and writer Jose Ortega y Gasset:

"Life is fired at us point-blank.... Where and when we are born, or happen to find ourselves after we are born, there and then, like it or not, we must sink or swim... There is no escape: we have something to do or have to be doing something always; for this life that is given us is not given us ready-made, but instead every one of us has to make it himself, each his own. This life that is given us is given us empty, and man has to keep filling it for himself... Such is our occupa- 


\section{tion." (Ortega y Gasset, 1957)}

From time to time, leaders contribute to the problematic circumstances into which they find themselves thrown. Perhaps they unintentionally set goals that are vague or unmeasurable or fall short in assigning clear accountabilities such that they find themselves in a difficult predicament. Other times, leaders are "thrown" by other people, which often represents an effort to thwart a change initiative. Leaders may be harassed directly, undercut, destabilized, or marginalized. Attempts to take the leader out are often the comeback for asking people to confront reality, contend with the brutal facts, and reprioritize their long-standing assumptions so they can tackle the challenges at hand (Heifetz \& Linsky, 2002). People push back because change represents loss and letting goletting go of ways of doing things they are comfortable with, letting go of their deep-seated beliefs. These ploys grow out of people's resistance to the change the leader is promoting. In attempting to "throw" the leader, people are striving to maintain what is familiar to them and avoid the discomfort of changing themselves.

\section{Implications for Leading Effectively}

Our "thrown situatedness" has enormous implications for leaders and the leadership they exercise. The idea that we live with a set of "givens" not chosen, but at the same time not entirely predetermined or fixed, often creates a dilemma that leaders must wrestle with. But at the same time, that struggle creates a paradoxical opportunity for freedom because the leader can choose how to be and act in any set of circumstances (Richardson, 1963).

Because we are capable of making sense of our circumstances, we can also attend to and "throw off" our thrownness by choosing from those possibilities (actions) that are available to us in a particular situation. Thrownness, notes Heidegger, "belongs to an entity which in each case is its possibilities, and is them in such a way that it understands itself in these possibilities and in terms of them, projecting itself upon them" (Heidegger, 1962 [1927]). This "understanding” directs us towards a certain range of ways of being-ways of analyzing the challenge, conveying it, and tackling it. In so doing, we make sense of who we are. For example, we understand ourselves as physicians in terms of our possibilities for interacting with patients. We understand ourselves as educators based on the way in which we teach and interact with our students. We understand ourselves as leaders in terms of our possibilities for exercising leadership. This experience of understanding our circumstances and demonstrating our potential through acting in the world is the essence of authentic freedom (Critchley, 2009).

As leaders, we are not just defined by our thrownness. To live authentically means to be, regardless of the circumstances we are thrown into, responsible for dealing with them responsibly. In this somewhat lengthy, but illuminating quote by psychologists Lyse Lebeau and Duart MacLean explain:

"Somehow, beyond our ability to grasp, we simply found ourselves here, in 
this place, at this time, with these parents, with this body... We are not born into something static, but are 'thrown' into something moving and dynamic; we are born 'on the run', so to speak. This 'thrownness' is not something over which we have control or which we have consciously chosen... Thus, we embark upon our life journey from a position of absolute innocence and we must assume absolute responsibility for where we find ourselves if we are to live authentically. We could not choose how we were 'thrown' but what we can choose, and this is the crucial responsibility of being human, is how to be with how we were thrown." (Lebeau \& MacLean, 2006)

While our thrownness does not eliminate our choices and actions as leaders, it does limit them. We are constrained by the historical customs into which we have been socialized. Because of our thrown nature, we have already inherited a specific language for dealing with our leadership challenges. We are constrained by our mental maps as well as any shortcomings in our know-how. Moreover, certain possibilities may be too risky—-we don't want to disenfranchise our supporters or lose our job. In the words of Berkeley scholar Michael Watts, "I have to work with what I have been and what I am now in order to become what I want to be in the future. Thus, ultimately, everything I am and do has been made possible by the 'already given' situation into which I was thrown." (Watts, 2014)

Our "being" as leaders is always a struggle between thrownness and possibility because the undertakings we engage in and the people we interact with-our students, our colleagues, and our families-matter to us in some way or another. We care about our future and the future of our work; that's what makes the sting of being thrown so raw. But rather than acquiescing and disengaging in the name of "I didn't sign up for this" or "Life is not fair", authentic leaders take responsibility for what was, what is, and what will be, regardless of the circumstances they are thrown into. It matters not who threw them, how they were thrown, why they were thrown, what the specifics were, or where they landed. Hyde stresses that "the authentic [leader] is not one that has managed to escape the everyday thrownness of human being; rather, [he or she] is a [leader] that has taken hold of that thrownness 'in its own way' ..., rather than continuing to be owned by it." (Hyde, 1994)

\section{Managing and Embracing our Thrownness}

The way in which leaders take responsibility for their thrown circumstances and learn from them reflects how these challenges occur for them and how they occur for themselves in dealing with them. We each "see" our leadership challenges differently. Some leaders "see" them as opportunities to make a difference; others see them as another headache. Still others run in the opposite direction. What allows exceptional leaders to "see" their thrown circumstances differently than most others do, is that they are able to frame them as opportunities to learn and change things (Souba, 2017) rather than framing them as, "Why am I getting the shaft again?" Our best leaders seize their challenges without shirking 
responsibility and, in so doing, set an example for others to follow. As Fox writes, "We did not nor could not choose the way we were thrown. We did not choose to exist, nor did we choose to exist in this particular body, with this particular family, at this particular time, in this particular place. What we can choose, and this is the crucial responsibility of being human, is how to be with how we were thrown. We are absolutely innocent in our thrownness, and we are absolutely responsible for how we relate to that thrownness." (Fox, 1997)

Thus, effective leaders see thrownness as just part of the leadership landscape. They rise above complaints, excuses, and blame. When something doesn't go well it doesn't take these individuals long to get beyond it because they are committed to a future bigger than they are. Leaders go from "inheriting a mess" to actually owning it. They see crucible (thrown) events as opportunities to learn and grow, and find their purpose. They choose, rather than acquiesce to, their thrown circumstances.

Thrown circumstances are usually upsetting and the mental and emotional challenges of exercising leadership can be brutal. Because leaders are routinely thrown into situations that often appear arbitrary, seemingly "come out of nowhere", and can cumulatively be overwhelming, they must find ways to stay calm and grounded. Leaders must learn to: 1) manage the heat and pressure that invariably characterize their thrownness; and 2) stay anchored in the midst of the volatility (Heifetz \& Linsky, 2002).

Trust, open communication, and transparency are critical to holding people together in the midst of the pressure, heat, and explosiveness that often arise in tough conversations. In the midst of the turbulence, the need to have all the answers can be a death blow for the leader. Furthermore, to survive personally leaders need a safe haven where they can reflect on the issues with which they are dealing, replenish their emotional stamina, and renew their commitment to their core values. In the words of Heifetz and Linsky, "you need to regularly step into the inner chamber of your being and assess the tolls those challenges are taking." (Heifetz \& Linsky, 2002) Self-reflection is an essential practice, one that is invariably enhanced by a confidant who can listen nonjudgmentally.

Very importantly, leaders must avoid conflating their personal self with their professional role. Who we are most fundamentally is not our job, title, status, or income. Over-identification with these "possessions" can get in the leader's way. When we take the ego's conceptualization of reality as the truth about who we actually are, we generally get into trouble (Baumann \& Taft, 2011). Dan Brown's words are helpful:

"The more I have a strong sense of self the more it serves as a central organizing principle for my daily experience, providing continuity over time and space so over the course of my life, as time elapses, I feel like the same person.... The mind constructs. It constructs an out-there world... If we make those constructions too real or too solid as if they are independently existing, the consequence of that is that we reify the world making it too real, too solid. That has two negative consequences. First, it has grab; a lot of my suffering of my daily life is orga- 
nized around self-grab, and second, it has the capacity to obscure my true nature." (Brown, 2017)

We often take for granted what it is to be human in the sense that we listen to the crowd, proceed aimlessly with the herd, rarely questioning. We tend to avoid the tough issues-most of us deal with our thrownness "in the manner of an evasive turning-away" (Heidegger, 1962 [1927]). While our thrown default way of being is to take the easy way out and follow the masses, leaders are willing to take the road less traveled and challenge the status quo. Rather than acquiescing to their "thrown situatedness", our best leaders do not cave; rather, they choose to deal with the issues at hand authentically. What it means to be free in life is to choose to be here, rather than resigning yourself to the fact that you are here.

A leader's compassion is sourced by his or her sober realization that life is an unchosen existence-we see this in disabilities, birth defects, educational disparities, and extreme poverty. This realization helps leaders be more sensitive and compassionate. Professor Terrilyn Sweep of the University of Queensland in Brisbane asks: How do we learn to embrace one another, "given that the superficial manifestations of our identity most concretely represent the unchosen aspects of our beings, for example, skin color, mode of dress and language (understood as our inherited genetic and cultural characteristics), by which we generally recognize and relate to each other?" (Sweep, 2016) Leaders must take the lead in creating a world that is anchored in diversity, equality, and inclusivity.

Great leaders teach others to deal with their thrownness by pointing out that thrownness is the substrate for learning. The way in which we are thrown is designed to provide us with opportunities to learn and grow despite the fact that the eventual outcome is uncertain. Our choices and decisions as leaders always take place in the context of not knowing how things will turn out. Some people take their thrown circumstances quite personally and can become stuck inside of conversations laced with culpability, pretexts, and objections. Until these accounts are dealt with and resolved, it is essentially impossible to take responsibility for creating a new future. Accordingly, leadership, especially in a volatile, unpredictable world where being thrown is the rule, is not for everyone. It requires deep self-awareness, and, very importantly, a rather detached relationship with this thing called "I" or "me."

Life as a human being is always a thrown existence-sometimes we feel like we've been thrown under the bus, thrown into a seemingly impossible predicament, thrown an unexpected curve, or thrown to the wolves. If you want to lead, you're going to get thrown, one way or another. People who dodge the accountabilities that thrownness entails are invariably poor leaders. For many individuals in leadership positions, their thrown default way of being is to shirk responsibility, sidestep the tough conversations, and avoid the elephant in the room that is dying to be acknowledged. Our best leaders confront the tough issues, recognizing that leadership is not about them but rather about the people the organization was created to serve. 
Recognizing that we are all thrown is the basis for enhancing our respect for one another. Sweep reminds us that "we are all individualized by a [thrown] life that is unique, but we are all united in the unchosen nature of it. Entering into relationships with a conscious awareness of the shared nature of our originary unchosen lives, is the basis for understanding each other" (Sweep, 2016).

Acceptance of the randomness and inevitability of being thrown, with its associated aggravations and annoyances, is a hallmark of effective leaders. Yet, this arbitrariness and inescapability that comes our way is, at the same time, not entirely deterministic. This grants leaders a somewhat paradoxical gateway to freedom, a journey on which they can discover purpose in their thrown humanity. All great leaders understand this. Where they go first to discover their authentic voice is within. It is here that they discover what they truly care about. This is not something they learn from a health farm or at a posh resort. They learn it on the journey itself.

\section{References}

Baumann, P., \& Taft, M. (2011). Ego: The Fall of the Twin Towers and the Rise of an Enlightened Humanity. NE Press: San Francisco.

Brown, D. (2017). The Sun is Always Shining.

https://aeon.co/videos/its-easy-to-get-caught-up-in-constructing-our-selves-but-whatdoes-it-cost-us

Critchley, S. (2009). Being and Time, Part 4: Thrown into This World. http://www.theguardian.com/commentisfree/belief/2009/jun/29/religion-philosophy

Fox, R. (1997). On Thrownness. http://www.focusing.org/apm_papers/fox.html

Heidegger, M. (1962) [1927]. Being and Time. J. Macquarrie, \& E. Robinson (Trans.). New York: Harper \& Row.

Heifetz, R., \& Linsky, M. (2002). A Survival Guide for Leaders. Harvard Business Review, $80,65-72$.

Hyde, R.B. (1994). Listening Authentically: A Heideggerian Perspective on Interpersonal Communication. In K. Carter, \& M. Presnell (Eds.), Interpretive Approaches to Interpersonal Communication, Albany, NY: SUNY Press.

Lebeau, L., \& Maclean, D. (2006). Awakening the Fire Within: Relationship, Leadership \& Self-Esteem. Bloomington, IN: Trafford.

Ortega y Gasset, J. (1957). Man and People. W. Trask (Trans.). New York: WW Norton.

Richardson, W. (1963). Heidegger: Through Phenomenology to Thought. The Hague: Martinus Nijhoff Publishers. https://doi.org/10.1007/978-94-017-6188-8

Souba, W. (2017). Hittability: The Leader's Edge. Academic Medicine, 92, 444-447. https://doi.org/10.1097/ACM.0000000000001498

Sweep, T. (2016). Accommodating Thrown-Being in the World. Ph.D. Thesis, Brisbane: The University of Queensland.

The Doors (1971). Riders on the Storm. Elektra Records.

Watts, M. (2014). The Philosophy of Heidegger. New York: Routledge. 